\title{
Effects of different reading texts on vocabulary gain, use and retention
}

\author{
Hatice Okyar $^{\mathrm{a} *}$ (iD), Abdulhamit Çakır ${ }^{\mathrm{b}}$ \\ ${ }^{a}$ Necmettin Erbakan University, Konya, Turkey \\ ${ }^{b}$ KTO Karatay University, Konya, Turkey
}

APA Citation:

Okyar, H., \& Çakır, A. (2019). Effects of different reading texts on vocabulary gain, use and retention. Journal of Language and Linguistic Studies, 15(1), 111-122.

\begin{abstract}
This study investigated whether encountering the target language words in variety of reading texts would have positive effects on vocabulary development or not. The participants of the study were $55 \mathrm{EFL}$ learners from a state university in Turkey, and two classes were randomly assigned to a control $(n=27)$ or an experimental $(n=28)$ group. 58 English target words in total were chosen to be used in the study. The learners in the experimental group learnt the words through reading texts, and then they repeated them in different reading texts. That is to say, these students had the opportunity to meet the target words in different types of reading texts. Contrary to this, the learners in the control group encountered the words in reading texts only once, and then they repeated them in word lists out of context. A vocabulary test as pre-, post- and delayed post-test was used to measure vocabulary gain and retention. The data obtained from the vocabulary test were analyzed through paired-samples t-tests and independent-samples t-tests to see how the implementation affected the learners' vocabulary development. Additionally, a writing task was used to find out the effects of the implementation on the learners' vocabulary production. The findings showed that encountering words in different reading texts was more effective for vocabulary gain, use and retention.
\end{abstract}

(C) 2019 JLLS and the Authors - Published by JLLS.

Keywords: Reading texts; context; vocabulary gain; vocabulary use; vocabulary retention

\section{Introduction}

An oft-cited quote from Wilkins (1972) highlights the great significance of vocabulary knowledge in language as follows: "Without grammar very little can be conveyed, without vocabulary nothing can be conveyed" (p. 111). This quotation clearly points to the crucial role of vocabulary knowledge for effective use of four language skills. As "words are the basic building blocks of language" (Read, 2000, p. 1), vocabulary knowledge seems to have an utmost importance for successful communication of ideas (Sedita, 2005). According to McCarthy, O'Keeffe and Walsh (2010), effective use of language is directly correlated to the word knowledge, which embraces correct pronunciation and production of the words.

"Corresponding author. Tel.: +90 3323238220

E-mail address: hokyar@erbakan.edu.tr 
Likewise, Schmitt (2010) and Alderson (2005) put forward that a big part of success in a language is largely based on good word knowledge. All of these clear explanations stress the absolute necessity of effective vocabulary instruction in EFL classes. Most of the teachers believe that lack of vocabulary knowledge prevent learners from communicating their ideas effectively and for that reason, more efficient allocation of classroom time to vocabulary as well as grammar seems very essential (Allen, 1983).

As learning the vocabulary of a new language is, without doubt, not an easy task for language learners to accomplish, vocabulary is expected to be one of the prominent subjects to be mainly focused on during language instruction (Oxford \& Crookall, 1990). Unfortunately, as Oxford and Crookall (1990) indicate, this is not the case in many language classes as learners are required to handle vocabulary on their own without any direct instruction. The main problem is that L2 learners are generally expected to learn the target words given to them in lists by heart or they are left without enough chance to practice the words they have just met (Oxford \& Crookall, 1990). Considering these problems, it seems a real necessity to search for the ways for effective vocabulary instruction.

\subsection{Effective vocabulary instruction and the role of context}

Considering the central role of vocabulary in language learning, many researchers have made valuable suggestions related to effective vocabulary learning and teaching. With regard to this, Nagy (2005) explains the components of successful vocabulary gain as "extensive exposure to rich language, both oral and written; and building generative word knowledge" (p. 28). In addition to this, many researchers (e.g. Bolger, Balass, Landen, \& Perfetti, 2008; Harmer, 2007; McCarten, 2007; Stahl, 2005; Takac, 2008) emphasize the importance of meaningful context for better vocabulary learning because seeing words in meaningful contexts can help learners make meaningful associations (Stahl, 2005). For Harmer (2007), the most appropriate way to introduce novel words is through varied contexts (e.g. reading texts or listening tracks) which can help learners understand the ways the words are used. Additionally, one of the results of the National Reading Panel (2000) draws attention to the significance of context -in the form of variety of reading texts- for effective vocabulary learning. Similarly, many researchers (e.g. Stahl, 2005; Stahl \& Nagy, 2006; Xu, 2009) put forward that exposure to words many times in reading texts contributes greatly to vocabulary development. Furthermore, Stahl and Nagy (2006) hold the opinion that "even for those words that are explicitly taught, much of students' knowledge of them ultimately comes from further encounters with those words in text" (p. 173). This may be because of the fact that exposure to words in texts sounds more realistic for both linguistic and psychological terms when compared to the encountering them in isolation out of texts (Schouten-van Parreren, 1989).

Encountering words in variety of texts many times rather than the mere repetition of them in isolation can lead to permanent learning (Stahl, 2005). Permanent learning is crucial here because there are no fixed rules for word learning, and this makes vocabulary, in comparison to phonology and grammar, more likely to be forgotten (Schmitt, 2010). With regard to this issue, Thornbury (2002) points to the necessity of words' transfer from short-term memory to long-term memory for successful vocabulary learning. Stahl and Nagy (2006) state that context can be helpful for words to be stored in long-term memory. Furthermore, one needs to encounter novel words multiple times for successful learning (Kamil \& Hiebert, 2005; McCarten, 2007; Nation \& Meara, 2002; National Reading Panel, 2000; Schmitt, 2000; Stahl \& Fairbanks, 1986; Stahl \& Nagy, 2006; Thornbury 2002). It is also crucial to keep in mind that these repetitions lead to more effective learning when they are meaningful to the learners (Oxford \& Crookall, 1990; Schmitt, 2010; Stahl, 2005). In other words, as Oxford and Crookall (1990) state, "sufficient exposure to the new target language word in meaningful, communicative, oral or written contexts is no doubt essential" (p. 23). In a similar vein, Schmitt (2010) suggests that "A learner 
must read enough so that a new lexical item will be met again before its memory trace disappears" (p. 257). For this reason, Schmitt (2010) recommends multiple encounters to words in variety of contexts for permanent learning of L2 vocabulary.

In the light of these explanations, this study attempted to investigate the effects of encountering words in context in the form of reading texts. The hypothesis of the study was that encountering the target words more than once in different reading texts is more beneficial for vocabulary gain, use and retention than repetition of them in word lists as isolated elements after encountering them only in a single reading text.

\section{Method}

\subsection{Participants}

The subjects of the study were 55 mechanical engineering students from a state university in Turkey. They were all native speakers of Turkish and learning English as a foreign language. Additionally, the participants were all freshman with a three-hour English class per-week. There were two classes at the beginning of the study, and these classes were randomly assigned to two treatment conditions. There were 28 and 27 students in the experimental and the control group, respectively. The first author of this study was also the instructor of both groups.

\subsection{Testing instruments}

\subsubsection{Vocabulary test}

A vocabulary test, which was composed of three parts, was designed to measure the effects of the implementation on vocabulary gain and retention. The first part of the test was comprised of eight fillin-the-blank questions. In this part of the test, the students were given eight sentences and nine words (one of them was extra) to fill in the blank in each sentence with the most appropriate word. The following sentence exemplifies the fill-in-the-blank part of the test:

"He is a good swimmer. He has no of water."

The second part of the test was composed of six word-definition matching questions, which required the students to find the English definition of each word. There were six words (e.g. surprising, bored, except, etc.) and seven definitions (one of them was extra) in this part of the test. Finally, the third part of the test consisted of eleven multiple-choice questions, which asked the students to choose the best answer among the four answer options. In order not to give any grammatical clues, the correct answer and the distractors of each item were selected from the same word class. The item below is an example from the multiple-choice test:

What is the between the two cars?
a) member
b) result
c) present
d) difference

After the testing instrument was developed, a native speaker checked the test to see if there were any ambiguities or problems related to the test items. There were totally 25 questions in the test, which covered all the 58 target words of the study. While each correct answer was given 1 point, each incorrect answer was awarded 0 points. In order to ensure the reliability of the test, it was first administered to 150 engineering students from a similar sample at the same university. The results of the analysis showed that the test was highly reliable ( $\mathrm{kr} 0.815$ ). To see both short-term and long-term effects of the treatment, the test was applied to the students as pre-, post- and delayed post-test in the study. 


\subsubsection{Writing task}

In addition to the above-mentioned vocabulary test, a writing task was also prepared to see how the students used the target words in their written production. In context-related studies, Baleghizadeh and Shahry (2011) strongly recommend to measure the effects of context on vocabulary production. Considering this, it was thought that it would be appropriate to see the effects of the implementation on word use of the students. The writing task included two writing topics, and each of them was provided with 9 target words to be used by the students. The first topic was related to the problems that the students had. Some questions as prompts (e.g. Think about a problem you have. Do you try to solve it or not?, What do you do when you have a problem?, How do you feel?) were given to the students to help them during their writing. Also, 9 target words (decision, argue, bored, rather, stress, relax, wise, for instance, choice) out of 58 were chosen to be used by the students in their writing texts. These words were thought to be the ones that were relevant to the writing topics. The second writing topic was related to the wars in the world, and again prompt questions and target key words (disagreement, respect, result, terrible, attack, enemy, brave, power, fear) were provided to the students. The students in each group wrote about these two topics. This task was administered to the students in each group only once two weeks after the implementation.

\subsection{Data collection procedure}

The book Password 1: A reading and vocabulary text by Butler (2003) was utilized during the implementation period. This book included high beginning level reading texts that were appropriate for the level of the participants. Besides, the reading texts in the book covered the most frequently used English words based on the analyses of many different corpora (e.g. Longman Corpus Network). Prior to the intervention, four reading texts were chosen to present the new vocabulary, and each of the three reading texts included 15 boldfaced target words while the fourth one contained 13 boldfaced target ones. In order to insert these 58 words into different reading texts, the researchers prepared six different types of reading texts (e.g. dialogues, letters, news report, advertisement) so that the students in the experimental group could meet the words in variety of texts. After all of the testing and reading materials were prepared, the implementation period started for both groups. As a first step of the implementation, both groups took the vocabulary pre-test. Then the students in each group were provided with the first reading text in which 15 target words were placed. Before the students started to read the text, the instructor asked some warm up questions (e.g. What does the title mean to you?) related to the text. Considering the ways of vocabulary learning and teaching (see Thornbury, 2002), some strategies were adopted to teach the target vocabulary. As a first step, the students were asked to read the text by focusing on the words written in bold without using dictionaries so that they could have opportunity to guess the meaning of the words from the text. When they finished reading, the instructor read the text aloud, emphasizing each target word and gave the definitions of them in English. In order to ensure that the students understood what each word means, L1 equivalents were also provided. These steps were same for both groups. However, in the following week, the students in the experimental group met the words of the previous week in different reading texts. This provided the students with the opportunity to meet the words in context more than once. In other words, the students in the experimental group had the chance to repeat the words in another reading text. However, this was not the case for the students in the control group. The students in the control group repeated the target words of the previous week in word lists. That is to say, they met the target words once more out of context in isolation. The implementation process continued for 5 weeks, and after this period, an immediate post-test was carried out for both groups. Additionally, with the purpose of seeing the effects of the implementation on vocabulary retention, a delayed post-test was used in the study. With regard to this, Schmitt (2010) states that delayed posttests are essential in vocabulary related studies because only these tests can provide reliable 
information about long-lasting learning. Additionally, Schmitt, considering the ideas of some researchers, puts forward that a delayed-test, when administered three weeks after the treatment, can show whether permanent learning occurred or not. Therefore, both groups in this study were administered the delayed post-test about a month after the application of the immediate post-test. In addition to this, a writing task was administered to both groups two weeks after the implementation period ended to see how the students used the words in their written production. The whole implementation process was completed in 9 weeks.

\section{Results}

\subsection{Results of the vocabulary test}

This study had a quasi-experimental design, and the quantitative data of the pre-, post- and delayed post-test were analysed using Statistical Package for the Social Sciences (SPSS) Version 18. Mean values, standard deviations and $\mathrm{p}$ values were calculated and displayed in tables for a more clear understanding of the effects of the implementation. For comparison of pre- and post-test measures within groups, paired-samples t-tests were run. In order to compare the mean scores of the experimental and the control group, independent-samples t-tests were conducted. The following table shows whether the pre-test mean scores of the groups were similar or not at the beginning of the study.

Table 1. Comparison of the pre-test scores of the groups

\begin{tabular}{lccccc}
\hline Groups & $\mathrm{N}$ & Mean & Std. deviation & $\mathrm{t}$ & $\mathrm{p}$ \\
\hline Experimental & 28 & 8.07 & 3.800 & -.043 & .966 \\
Control & 27 & 8.11 & 3.055 & & \\
\hline
\end{tabular}

As shown in table 1, the mean score of the pre-test was found as 8.07 and 8.11 for the experimental and the control group, respectively. The results of the analysis show that there was not any statistically significant difference between the groups' pre-test scores $(\mathrm{p}>0.05)$, which indicates that both groups were similar in terms of target vocabulary knowledge prior to the intervention.

Paired-samples t-tests were employed to see whether there was an increase in the scores of each subject in both groups from pre- to post-test. Tables 2 and 3 present the paired samples t-test results regarding pre- and post-test.

Table 2. Paired-samples t-test result of the experimental group

\begin{tabular}{lccccc}
\hline & $\mathrm{N}$ & Mean & Std. deviation & $\mathrm{t}$ & $\mathrm{p}$ \\
\hline Pre-test & 28 & 8.07 & 3.800 & -10.444 & .000 \\
Post-test & 28 & 16.27 & 4.106 & & \\
\hline
\end{tabular}

As the data displayed in table 2 reveal, the mean scores of pre- and post-test in the experimental group were 8.07 and 16.27, respectively. The results show that there was a statistically significant difference between the pre and post-test scores $(\mathrm{p}=.000)$. The significant increase of the mean score 
from pre- to post-test indicates that encountering words in different reading texts helped learners' vocabulary gain.

Table 3. Paired-samples t-test result of the control group

\begin{tabular}{lccccc}
\hline & $\mathrm{N}$ & Mean & Std. deviation & $\mathrm{t}$ & $\mathrm{p}$ \\
\hline Pre-test & 27 & 8.11 & 3.055 & -6.336 & .000 \\
Post-test & 27 & 12.15 & 2.685 & & \\
& & & & & \\
\hline
\end{tabular}

As table 3 reveals, the mean scores of pre- and post-test in the control group were 8.11 and 12.15, respectively. The findings indicate a statistically significant difference between pre- and post-test scores of the control group $(\mathrm{p}=.000)$. Considering this, it can be said that encountering words in a single reading text and then repeating them in lists as isolated elements also helped learners' vocabulary development.

The obtained results from the immediate post-tests were compared through independent-samples ttest as in the following table.

Table 4. Independent-samples t-test result of the immediate post-test

\begin{tabular}{lccccc}
\hline Groups & $\mathrm{N}$ & Mean & Std. deviation & $\mathrm{t}$ & $\mathrm{p}$ \\
\hline Experimental & 28 & 16.27 & 4.106 & 4.386 & .000 \\
Control & 27 & 12.15 & 2.685 & & \\
\hline
\end{tabular}

Table 4 displays the comparison of the immediate post-test scores of both groups. The post-test mean scores of the experimental and the control group were 16.27 and 12.15 , respectively. There was a statistically significant difference between the groups' post-test scores $(\mathrm{p}=.000)$. The experimental group performed better than the control group in the immediate post-test.

In order to see the long-term effects of the implementation, the delayed post-test results of the groups were compared as the following table illustrates.

Table 5. Independent-samples t-test result of the delayed post-test

\begin{tabular}{lccccc}
\hline Groups & $\mathrm{N}$ & Mean & Std. deviation & $\mathrm{t}$ & $\mathrm{p}$ \\
\hline Experimental & 28 & 15.04 & 4.469 & 3.154 & .003 \\
Control & 27 & 12.01 & 2.266 & & \\
\hline
\end{tabular}

As the table above reveals, the delayed post-test mean scores for the experimental and the control groups were 15.04 and 12.01 , respectively. The $\mathrm{p}$ value $(\mathrm{p}=.003)$ shows that there was a statistically significant difference between the groups' delayed post-test scores. In other words, the experimental group outperformed the control group in the delayed post-test. 


\subsection{Results of the writing tasks}

There were two writing topics, and the students were asked to write two short paragraphs by using the target words provided to them. The main purpose here was to see whether the students would be able to use the target words correctly in sentences. Some errors, such as omission of articles (a, an, the), were not taken into account while analyzing word use in sentences. The occurrence of the target words in each paper was tallied, and then the number of correct uses of each word in groups was shown in the table. The results related to the two writing tasks are demonstrated in the following table.

Table 6. Results of the word use in the writing task 1

\begin{tabular}{lcc}
\hline Target words & $\begin{array}{c}\text { Number of correctly used words } \\
\text { in the experimental group } \\
\text { (f) }\end{array}$ & $\begin{array}{c}\text { Number of correctly used words } \\
\text { in the control group } \\
\text { (f) }\end{array}$ \\
\hline Decision & 12 & 8 \\
Argue & 10 & 4 \\
Bored & 9 & 6 \\
Rather & 11 & 5 \\
Stress & 7 & 0 \\
Relax & 13 & 3 \\
Wise & 12 & 1 \\
For instance & 9 & 2 \\
Choice & 18 & 1 \\
\hline
\end{tabular}

Table 7. Results of the word use in the writing task 2

\begin{tabular}{lcc}
\hline Target words & $\begin{array}{c}\text { Number of correctly used words } \\
\text { in the experimental group }\end{array}$ & $\begin{array}{c}\text { Number of correctly used words } \\
\text { in the control group } \\
\text { (f) }\end{array}$ \\
\hline Disagreement & 11 & 5 \\
Respect & 17 & 5 \\
Result & 11 & 1 \\
Terrible & 18 & 11 \\
Attack & 22 & 2 \\
Enemy & 16 & 4 \\
Brave & 14 & 3 \\
Power & 10 & 5 \\
Fear & 10 & 4 \\
\hline
\end{tabular}

As table 6 and 7 illustrate, there were totally 18 words to be used by the students in their writing. The number of correctly used words was higher in the experimental group than that of the control group. Considering this, it can be said that the students who saw the usage of words in different reading texts produced more correct sentences by the target words.

\section{Discussion}

It was hypothesized that experiencing target L2 words in different reading texts would be more beneficial for vocabulary gain, use and retention than exposure to them in a single reading text plus repetition of them in word lists out of context. The overall findings of the study are consistent with the 
suggested hypothesis as the experimental group performed better than the control group on vocabulary test. This shows the positive impacts of practicing words in variety of reading texts on vocabulary gain. It is also important to note that both groups' scores increased from pre to post vocabulary test. This indicates that encountering words in a single text, and then repeating them out of context had also positive effects on students' vocabulary learning. This may be because of the fact that learners in the control group first met the words in a meaningful context, and so this may have caused them to increase their scores from pre- to post-test. However, the comparison of the two groups' test results indicated that encountering words in different reading texts produced better results. Considering this, it can be said that contextual variety may have helped learners in the experimental group to do better than the students in the control group. Therefore, the results are in line with the ideas of some researchers (e.g. Nitsch, 1978; Stahl, 1991, 2009) who underline the positive effects of multiple contexts on vocabulary learning rather than a single context.

The hypothesis of the study was also related to the use of the target words. That is to say, it was assumed that encountering words in different reading texts would lead to more successful use of the target words than encountering them in a single text plus repetition of them out of context. As more successful word production was observed in the experimental group, it can be said that the results are in line with the hypothesis. This may have been due to experiencing the target word use in various texts. This finding is in line with the idea that effective use of words is positively correlated to the analysis of words in contexts (Stahl, 2005). That is to say, encountering words in both written and spoken language can be helpful for successful production of the words (Nagy, 2005). The hypothesis of the study also indicated that exposure to words in different reading texts would be more beneficial for vocabulary gain in the long-run. The comparison of the delayed post-test results showed that the students in the experimental group outperformed the ones in the control group. Considering this, it can be said that the findings are consistent with the hypothesis of the study. These findings are also in line with the claims of Stahl (2005), who says that it is easier to remember the information that is meaningful to us. Additionally, the results support the ideas of Stahl (2005), Thornbury (2002), Gairns and Redman (1986) who suggest that repetition of words in various contexts rather than in the same context is more effective for learning and retention of vocabulary.

The general results of this study support the findings of Baleghizadeh and Shahry (2011) who also highlight the positive effects of practicing words in context. These researchers designed a study to compare the effects of two methods on learning of the L2 words. In their study, they chose 20 English words, and the learners met half of these words in three context sentences, together with their equivalents in their native language. However, for the next half of the words, learners met only their equivalents in their mother tongue without any context. The results of the post and delayed post-test showed that learning words in context led to more successful learning. This study's findings also support what Soureshjani (2011) found in his study. Soureshjani compared the effects of teaching target language words in and out of context. One of the groups memorized the words in lists with their Persian equivalents, and the other one encountered the words in sentences. Considering the findings, Soureshjani concluded that using context for vocabulary teaching was more beneficial.

The results are also in line with the findings of the previous L1 related studies that focused on the role of context in vocabulary learning. For instance, Nash and Snowling (2006) investigated the ways for developing vocabulary knowledge of children with poor English vocabulary knowledge. With this aim in mind, these researchers included two groups in their study. The children in the groups were native speakers of English and their age ranged between 7-8 years. While the first group learnt vocabulary through dictionary definitions, the second group tried to derive the meaning of the new words through the clue words that were placed into very short texts. The immediate post-test results demonstrated equal development in both groups; however, delayed post-test results revealed that the context method was 
more effective in the long-term in comparison to the other method. Another L1 related study, conducted by Bolger, Balass, Landen and Perfetti (2008), aimed to determine whether varied contexts were effective in teaching some rarely used English words to the native speakers of English. One of the main findings of the study revealed that encountering words in various contexts was more effective for learning abstract meanings than repeating them in a single context. In line with the aforementioned studies, this current study underlines the importance of context in vocabulary learning. Furthermore, it highlights the key role of multiple contexts in the form of reading texts for more effective vocabulary gain, use and retention.

\section{Pedagogical implications and suggestions for further study}

The findings of the study indicate that experiencing the target language words in different reading texts can be helpful for effective vocabulary learning. The results show that a single reading text plus repetition of the words in word lists as isolated elements may not be as effective as exposure to words in variety of reading texts. Therefore, based on the results, this study highlights the crucial role of contextual diversity in vocabulary learning. This study also underlines that repetition of the words in different contexts can have more positive effects on vocabulary use and retention than repetition of them out of context. For this reason, it seems better for L2 learners to practice the words multiple times in different meaningful entities for permanent learning because context enables learners to make meaningful connections (Stahl, 2005).

Considering the importance of context, language teaching materials can be designed in a way that provides learners with multiple encounters with the words in meaningful contexts. Also, L2 instructors can create their own reading texts which cover the target words and allow the repetition of them many times. Additionally, future studies can investigate the effects of context on vocabulary learning from different aspects so that well-grounded generalizations can be made. In this study, different reading texts were used as a context, and future studies can also search for the effects of different types of contexts considering the other skills of language. For instance, the effects of listening activities in meaningful contexts on vocabulary development can be investigated. This study's sample was composed of university level students, so future studies may investigate the effects of context on vocabulary gain of young learners. Finally, this study focused on the effects of the implementation on written production of words; therefore, future research studies can investigate the effects of various contexts on both written and spoken production of the target language words.

\section{Note}

This article is based on the MA thesis of the first author.

\section{References}

Alderson, J. C. (2005). Diagnosing foreign language proficiency. London: Continuum.

Allen, V. F. (1983). Techniques in teaching vocabulary. New York: Oxford University Press.

Baleghizadeh, S., \& Shahry, M. N. N. (2011). The effect of three consecutive context sentences on EFL vocabulary learning. TESL Canada Journal, 28(2), 74-89. 
Bolger, D. J., Balass, M., Landen, E., \& Perfetti, C. A. (2008). Context variation and definitions in learning the meanings of words: An instance-based learning approach. Discourse Processes, 45(2), 122-159.

Butler, L. (2003). Password 1: A reading and vocabulary text. New York: Longman.

Gairns, R., \& Redman, S. (1986). Working with words: A guide to teaching and learning vocabulary. Cambridge: Cambridge University Press.

Harmer, J. (2007). The practice of English language teaching (4th ed.). Pearson: Longman.

Kamil, M. L., \& Hiebert, E. H. (2005). Teaching and learning vocabulary: perspectives and persistent issues. In E. H. Hiebert and M. L. Kamil (Eds.), Teaching and learning vocabulary: Bringing research to practice (pp. 1-23). Mahwah, NJ: Lawrence Erlbaum.

McCarten, J. (2007). Teaching vocabulary: Lessons from the corpus, lessons for the classroom. New York: Cambridge University Press.

McCarthy, M., O'Keeffe, A., \& Walsh, S. (2010). Vocabulary matrix: Understanding, learning, teaching. Hampshire: Cengage Learning.

Nagy, W. (2005). Why vocabulary instruction needs to be long-term and comprehensive. In E. H. Hiebert and M. L. Kamil (Eds.), Teaching and learning vocabulary: Bringing research to practice (pp. 27- 44). Mahwah, NJ: Lawrence Erlbaum.

Nash, H., \& Snowling, M. (2006). Teaching new words to children with poor existing vocabulary knowledge: A controlled evaluation of the definition and context methods. International Journal of Language and Communication Disorders, 41(3), 335-354.

Nation, I. S. P., \& Meara, P. (2002). Vocabulary. In N. Schmitt (Ed.), An introduction to applied linguistics (pp. 35-54). London: Arnold.

National Reading Panel (2000). Teaching children to read: An evidence-based assessment of the scientific research literature on reading and its implications for reading instruction: Reports of the subgroups. Bethesda, MD: National Institute of Child Health and Human Development.

Nitsch, K.E. (1978). Structuring decontextualized forms of knowledge. Unpublished doctoral dissertation, Vanderbilt.

Oxford, R., \& Crookall, D. (1990). Vocabulary learning. A critical analysis of techniques. TESL Canada Journal, 7(2), 9-30.

Read, J. (2000). Assessing vocabulary. Cambridge: Cambridge University Press.

Schmitt, N. (2000). Vocabulary in language teaching. Cambridge: Cambridge University Press.

Schmitt, N. (2010). Researching vocabulary: A vocabulary research manual. Basingstoke: Palgrave Macmillan.

Schouten-van Parreren, M. C. (1989). Vocabulary learning through reading: which conditions should be met when presenting words in texts? AILA Review, 6, 75-85.

Sedita, J. (2005). Effective vocabulary instruction. Insights on Learning Disabilities, 2(1), 33-45.

Soureshjani, K. H. (2011). The effect of contextualizing and decontextualizing techniques on lexicaloriented knowledge of Persian EFL language learners. Theory and Practice in Language Studies, 1(5), 547-552. 
Stahl, S. A. (1991). Beyond the instrumentalist hypothesis: Some relationships between word meanings and comprehension. In P. Schwanenflugel (ed.), The psychology of word meanings (pp. 157-178). Hillsdale, N.H.: Lawrence Erlbaum Associates.

Stahl, S. A. (2005). Four problems with teaching word meanings (and what to do to make vocabulary an integral part of instruction). In E. H. Hiebert and M. L. Kamil (Eds.), Teaching and learning vocabulary: Bringing research to practice (pp. 95-114). Mahwah, NJ: Lawrence Erlbaum.

Stahl, S. A. (2009). Words are learned incrementally over multiple exposures. In M. F. Graves (Ed.), Essential readings on vocabulary instruction (pp.69-71). Newark, DE: International Reading Association.

Stahl, S. A., \& Fairbanks, M. M. (1986). The effects of vocabulary instruction: A model-based metaanalysis. Review of Educational Research, 56(1), 72-110.

Stahl, S. A., \& Nagy, W. E. (2006). Teaching word meanings. London: Lawrence Erlbaum Associates.

Takac, V. P. (2008). Vocabulary learning strategies and second language acquisition. Clevedon, UK: Multilingual Matters.

Thornbury, S. (2002). How to teach vocabulary. Malaysia: Pearson Education Limited.

Wilkins, D. A. (1972). Linguistics in language teaching. London: Arnold.

$\mathrm{Xu}$, J. (2009). An experimental study on the effects of different reading tasks on L2 vocabulary acquisition. English Language Teaching, 2(3), 69-79.

\section{Farklı okuma parçalarının kelime kazanımına, kullanımına ve kalıcılığına etkisi}

\section{$\ddot{\mathbf{O} z}$}

Bu çalışma hedef dile ait kelimelere farklı okuma parçalarında karşılaşılmasının kelime gelişimine olumlu etki edip etmeyeceğini araştırmıştır. Çalışmaya Türkiye'de bir devlet üniversitesinden İngilizce'yi yabancı dil olarak öğrenen 55 öğrenci katılmıştır ve çalışmaya kontrol (27 kişi) ve deney grubu (28 kişi) olmak üzere iki grup dahil edilmiştir. Çalışmada kullanılmak üzere toplamda 58 İngilizce kelime seçilmiştir. Deney grubundaki öğrenciler kelimeleri okuma parçalarında öğrenmiş ve daha sonra bu kelimeleri farklı okuma parçalarında tekrar etmişlerdir. Yani, bu öğrenciler kelimeleri çeşitli okuma parçalarında görme firsatını yakalamışlardır. Bunun aksine, kontrol grubundaki öğrenciler kelimelere okuma parçasında sadece bir kez karşılaşmış ve daha sonra bu kelimeleri bağlam dışında kelime listelerinde tekrar etmişlerdir. Kelime kazanımını ve kalıcılığını ölçmek için ön, son, ve geciktirilmiş son test olarak bir kelime testi kullanılmıştır. Uygulamanın kelime gelişimine etkisini görmek için kelime testinden elde edilen veriler bağımlı örneklem $t$ testi ve bağımsız örneklem $t$ testi ile analiz edilmiştir. Buna ek olarak, uygulamanın kelime üretimine etkisini bulmak için yazma akvitesi kullanılmıştır. Bulgular, kelimelere farklı okuma parçalarında karşılaşmanın kelime kazanımı, kullanımı ve kalıcığı için daha etkili olduğunu göstermiştir. 


\section{AUTHOR BIODATA}

Hatice Okyar currently works as an assistant professor at Necmettin Erbakan University, School of Foreign Languages, Konya, Turkey. Her research interests include EFL teaching and ELT methodology.

Abdulhamit Çakır is working as an assistant professor at KTO Karatay University, School of Foreign Languages, Konya, Turkey. His research interests are discourse analysis and critical reading in language teaching. 